\title{
3. Gibbons and hominoid ancestry
}

\author{
Peter Andrews and Richard J Johnson
}

\section{Introduction}

Gibbons form a monophyletic group that differs from other hominoid primates, both in behaviour and anatomy. They are found exclusively in eastern Asia, and although evidence from DNA suggests their lineages diverged close to the time of hominoid origins (Goodman et al., 1998), the species array seen today in Asia did not speciate until closer to 6 Mya (Hayashi et al., 1995; Groves, 2001). Their taxonomy has been clarified by the work of Groves (2001), but their evolutionary history is still poorly understood. There is next to no fossil evidence to show when and where the gibbon lineage emerged and speciated, but comparisons with the great apes provide evidence of their shared common ancestor. Gibbon locomotor morphology, which formed the basis of our shared work with Colin Groves (Andrews and Groves, 1976), is unique in the animal world, but attempts to link gibbon anatomy with that of the great apes has generated much confusion not only in ape evolution but also in human evolution. The question 'were human ancestors brachiators?' provides a good instance of this, and it seriously retarded evolutionary interpretations of human evolution during the middle part of the twentieth century (and is still with us today). We will review this evidence here, followed by the fossil evidence for gibbon evolution, little as it is, and attempt to reconstruct the gibbon common ancestor. Three evolutionary scenarios will be presented based on these two lines of evidence, with a third based on the evolutionary significance of the loss of the uricase gene during gibbon evolution (Johnson and Andrews, 2010).

\section{Hylobatid taxonomy and morphology}

Gibbons (family Hylobatidae) share some characters with the great apes, including the relatively large size and the configuration of the brain; the morphology of the teeth; long clavicle; the orientation and dorsal positioning of the scapula; the cranial orientation and shape of the head of the humerus; the free rotatory movements of the radioulnar joints; the mobility of the wrist and hand, in particular the meniscus development of the wrist; the shortened caudal and lengthened sacral regions of the vertebral column; the expanded ilium; the loss of the tail; the shape of the thorax; the presence of a vermiform appendix; 
and the disposition of the abdominal viscera (Napier, 1960, 1963; Lewis, 1971, 1989; Groves, 1972, 1986; Preuschoft et al., 1984). They have many adaptations for below branch suspensory locomotion, or brachiation, for example their elongated arms and the automatic hook formed by their hands when they extend their arms - they literally cannot extend their fingers when their arms are extended, an excellent device for hanging securely on to branches. They may move bipedally on larger branches of trees (Avis, 1962), and their legs are relatively long compared with the size of their bodies. They are strictly arboreal, living in tropical rainforest, with a diet consisting mainly of fruit, and they are 5 to 12 kilograms in body weight. In all of these morphological characters, gibbons appear to be derived relative to monkeys and other primates.

In many characters, gibbons are also derived relative to the earliest known fossil apes, so that they may have branched off from the other apes soon after the appearance of this fossil group. The earliest fossil that can be shown to share hominoid synapomorphies is Proconsul heseloni (Ward et al., 1991, 1993), which is from $18 \mathrm{Ma}$ deposits on Rusinga Island, Kenya, but other species of the genus extend back in time to 20 to $22 \mathrm{Ma}$. There is also a fossil monkey from similar aged deposits, and recently a monkey-like tooth has been described from the Rukwa rixft in southern Tanzania dated to 25 Ma (Stevens et al., 2013). From the same site at Rukwa is a fossil tooth row showing a remarkable degree of similarity to Rangwapithecus gordoni (Stevens et al., 2013), but it should be pointed out that there are no characters that establish either this species or the new Rukwapithecus fleaglei as members of the hominoid lineage. Their elongated molars and adaptations for more folivorous diets (Kay, 1977) are shared with monkeys rather than apes, and it may be that $R$. gordoni and $R$. fleaglei should be distinguished as a separate family, together with 'nyanzapithecines' and separate from hominoids (Harrison, 2002). Be that as it may, there is also evidence for gibbon divergence prior to the loss of the uricase gene (see below), a loss common to all living hylobatids, before 13.1 Ma (Keebaugh and Thomas, 2010) or 9.8 Ma (Oda et al., 2002).

The family is divided into four genera and as many as 14 to 18 species (Groves, 2001; Brandon-Jones et al., 2004; Thinh et al., 2010). Genus Hylobates (named as subgenera in Groves, 2001) is the most widespread with seven species; Bunopithecus hoolock and Symphalangus syndactylus are monospecific genera, and Nomascus has six species. They live exclusively in tropical and subtropical forests of eastern Asia where they have a unique form of locomotion, brachiation, which is common to all 14 species (Napier, 1963; Avis, 1962; Lewis, 1971). At the time when Colin and lead author, PA, wrote their paper on gibbon locomotion, there was much discussion about brachiation, what it is and how common it is in other primates. Much of this was the result of anatomical studies of the primate shoulder and forearm (Napier, 1963; Ashton and Oxnard, 1963, 1964), 
of the skeleton (Schultz, 1973) and of the hand (Lewis, 1971), and following in this tradition we undertook a series of anatomical dissections of the gibbon shoulder and forearm. Colin and PA found that:

The most striking thing, perhaps, about the musculature of the gibbon is the prevalence of interlinked muscle systems; indeed Hylobates lar may be crudely characterised as a mass of muscle chains. A long chain runs from pectoralis major via biceps brachii to flexor digitorum sublimis, and this is reinforced by a chain from latissimus dorsi via dorsoepitrochlearis to biceps. Further cleidodeltoideus (in the lar group only) inserts into pectoralis major. Separate from this multified chain is a second linking the caudal head of subscapularis with the deep fibres of teres major. Functionally a muscle chain acts to transmit the contraction of one muscle to the action of a second. (Andrews and Groves, 1976: 207)

There are variations within the hylobatids, as we and others have pointed out (references in Andrews and Groves, 1976), but these are minor compared with the species of great apes and humans. Even the spider monkey, which comes closest to gibbons in its form of locomotion and in its specialisations for below-branch locomotion, lacks the specialised interlinked muscle systems so characteristic of gibbons. They are absent in the great apes, and we concluded that characters for brachiation, and for suspensory locomotion in general, must be tied to the hylobatids, and the absence of these characters in great apes suggests a nonsuspensory evolutionary history. Characters such as the broad thorax, which are sometimes put forward as evidence of suspensory function in the great apes, together with associated characters of elongated clavicle and position of the scapula, are rather allometrically associated with increase in body size within primates, and the broad thorax in hylobatids is an exception to this allometric gradient (Andrews and Groves, 1976). This is consistent with fossil evidence (see below), which shows that for the first eight million years of the known fossil record of apes, the thorax was narrow and deep like that of monkeys. The same argument applies to the 'long' arms in gibbons and great apes; in the latter, their length in the African apes is on the same allometric gradient as that of monkeys (and humans), and while orangutan arms are slightly longer than expected for their body size, it is only the gibbons that have arm lengths outside the allometric gradient (Biegert and Maurer, 1972; Aiello, 1981; Jungers, 1984). We concluded by saying:

Where differences in morphology occur between gibbons and Great Apes, we conclude that, potentially, the condition seen in gibbons is that adaptive for brachiation. In many cases the functional interpretation significantly relates the condition to brachiation, but in some cases the features can be interpreted as adaptive for upright posture of mobility of forelimb, both necessary but not exclusive attribute of brachiation. It is 
in these features that Great Apes resemble gibbons, and it is concluded that they share a common feeding adaptation, despite their very different habitats, involving feeding in a stationary upright posture by reaching all round with the mobile forelimbs. (Andrews and Groves 1976: 213)

References to and justifications of these conclusions are set out in full in our long 1976 article and cannot be repeated here. The message we wish to convey here is that the gibbons formed a monophyletic group marked by unique behaviour and morphology that are shared to a great extent by all hylobatid species. It has also become apparent from molecular studies that gibbon speciation was both recent and sudden, either as a vicariant event or a rapid radiation at the end of the Miocene period (Israfil et al., 2011). We will now look to the fossil record to see if any of the features present today in living hylobatids may be seen in any known fossil ape.

\section{Fossil evidence}

It is a remarkable thing that despite their origin in the Miocene, hylobatids are not known in the fossil record earlier than the Middle Pleistocene. There are isolated teeth from Middle Pleistocene deposits in China and Indonesia, and Matthews and Granger (1923) described Bunopithecus sericus from Szechuan, which is indistinguishable from hoolock gibbons. Delson (1977) described a number of isolated teeth, but without attributing them to species, and Hooijer (1960) described numerous siamang teeth from Middle to Late Pleistocene sites in Indonesia. All are indistinguishable from living species of hylobatid and tell us nothing about the evolution of the lineage.

There are several reasons that might explain why the fossil record is so poor. Gibbons did not differentiate until relatively late in hominoid evolution, about the same time as the African ape and human clade, but while there is a good fossil record for early humans there is almost none for the great apes. DNA evidence shows that gibbons split off from the other apes and humans well before the orangutan divergence, but it may be that early species of fossil gibbon were extremely rare, and the sparse fossil record of fossil apes has so far failed to recover any. It is possible, even likely, that early gibbons did not look anything like modern gibbons, the characteristics of which almost certainly appeared late in their evolution, and it may be that some fossil gibbons are already known, but since they are not recognisable as gibbons they are not generally accepted as such. Finally, it might be also that gibbons were restricted to dense tropical forest, unlike the majority of fossil apes (see below), and the rarity of fossil sites representing forest habitats means that no fossil gibbons have been recovered. 
It is also the case with the great apes that few fossil apes can definitively be assigned to any of the great ape lineages. There is a fossil orangutan skeleton from middle Pleistocene deposits in Vietnam (Bacon and Long, 2001), fragmentary remains of chimpanzees in Africa, also from the Middle Pleistocene (McBrearty and Jablonsky, 2005; Pickford and Senut, 2005), and no fossil gorillas are known at all. It is the human lineage that is by far the best represented in the fossil record.

\section{Morphology of fossil apes}

We will first briefly review the evidence for morphological variation in fossil apes. Fossil apes span the last 20 million years, restricted initially to Africa in the early Miocene and spreading into Europe and Asia during the middle Miocene.

The earliest known apes are the proconsulids from the early Miocene, and they are characterised by the following key morphologies (described in Table 3.1).

Table 3.1: Morphological features of proconsulids related to their form of locomotion.

\begin{tabular}{|l|}
\hline Torsion of the humeral head \\
\hline Mobile shoulder joint \\
\hline Mobile elbow joint \\
\hline Narrow chest \\
\hline Long curved back \\
\hline Relatively long thumb \\
\hline Opposable thumb, non-rotatory \\
\hline Non-weight-bearing wrist and hand \\
\hline Relatively short hand \\
\hline Narrow gripping foot \\
\hline Powerful flexor muscles for gripping branches \\
\hline Molars had low degrees of shearing \\
\hline
\end{tabular}

Source: Compiled from sources on proconsulid morphology. All sources in reference list.

The conclusion to be drawn from the morphology of proconsulids is that they were arboreal climbers, moving on the tops of branches, but they were not habitual leapers rather moved slowly and powerfully in the trees. They were mainly fruit eaters with body sizes varying from $9-11 \mathrm{~kg}$ to $63-83 \mathrm{~kg}$, from siamang size to larger than chimpanzees, and some degree of terrestrial activity is indicated, particularly for the larger species, which were as big as chimpanzees or even bigger (Le Gros Clark and Leakey, 1951; Napier and Davis, 1959; Napier, 1960; Andrews, 1978, 1992; Walker and Pickford, 1983; Walker et al., 1983, 
1993; Rose, 1983, 1984; Beard et al., 1986; Gebo et al., 1988; Rafferty, 1988; Lewis, 1989; Walker and Teaford, 1988, 1989; Ward, 1993; Begun et al., 1994; Teaford, 1994; Rafferty et al., 1995; Ward et al., 1995; Harrison, 2002; Gebo et al., 2009). Primates at the upper end of the size range and living in woodland (non-forest) environments, must have been partly terrestrial, as in chimpanzees and gorillas today, for they were too large to move easily between arboreal pathways. Mike Rose has made a particularly telling point when he said: When I look at the postcranial bones from the Miocene apes, I get a fairly consistent pattern from many species, but it is nothing like what we see in modern apes. Maybe we should consider the ones that survived as the bizarre ones.

Dendropithecus macinnesi, an early Miocene ape from the same sites and levels as the proconsulids, was described originally by Le Gros Clark and Thomas (1951), who showed its similarities to hylobatids based on the gracile limb bones, which were taken to indicate suspensory locomotion in trees. Limb proportions were not gibbon-like, however, but more similar to those of spider monkeys. Andrews and Simons (1977) agreed with this interpretation, placing the new genus Dendropithecus in Hylobatidae, but in many respects it was shown that the morphology of the limb bones was more like that of colobine monkeys, the most arboreal of Old World monkeys.

There is also increasing evidence that early Miocene apes did not, for the most part, live in tropical forests but are mostly found associated with woodland habitats. The proconsulids (and Dendropithecus) at Rusinga Island are associated with a flora, which preserved a rich plant assemblage (Collinson et al., 2009) dominated by deciduous woodland tree species. There were very few twigs with thorns such as are found on more arid adapted species of Acacia or Balanites, and there was no evidence of forest trees. Broadleaved deciduous woodland is therefore indicated by the Rusinga flora. Evidence of large forest trees is known from Mfwangano Island, and the faunas from a few levels at Songhor and Koru suggest localised forest as well (Collinson et al., 2009).

Early in the middle Miocene, apes emigrated from Africa, initially in small numbers but later in the middle Miocene in greater numbers. Three groups are known at this stage, afropithecines, kenyapithecines and griphopithecines, and they share the following characters: relatively broad upper central incisors; lower crowned and relatively robust canines; enlarged premolars that are relatively long; molars with thick enamel, low dentine relief; long curved back; forelimbs adapted for both climbing and terrestrial locomotion; stiffer lower back (than proconsulids) analogous but not homologous to the condition in the living great apes; hand proportions indicate both arboreal and terrestrial locomotion; the foot was adapted for powerful grasping. 
Body sizes were within the range seen in the proconsulid species, estimated at 35 to $55 \mathrm{~kg}$, and environments were mainly woodland or even open woodland in Africa and subtropical woodlands in Europe (Harrison, 2002). Clearly, primates of this size, living in relatively open canopy woodlands, would have had to spend part of their time on the ground. The thick enamel of their teeth suggest a harder, coarser fruit and nut diet compared with proconsulids (Tekkaya, 1974; Alpagut et al., 1990, 1996; Teaford, 1988, 1991; Harrison, 1992; McCrossin and Benefit, 1997; McCrossin et al., 1998; Nakatsukasa et al., 1998, 2007; Begun and Güleç, 1998; King et al., 1999; Ishida et al., 1999, 2004; Ward, 1993; Ward et al., 1995; Kelley et al., 2000, 2002, 2008; Kelley, 2002, 2008; Ungar, 2007; Ersoy et al., 2008; Nakatsukasa, 2008).

During the second half of the middle Miocene and extending into the late Miocene, there was a greater proliferation of fossil apes in Europe and Asia. There are also a few genera and species known in Africa. The taxonomic status of subfamily Dryopithecinae has passed through several stages in its history, from the time when it included almost all known fossil apes, after the 1965 revision by Elwyn Simons and David Pilbeam (Simons and Pilbeam, 1965), to the later part of the twentieth century when almost everything except Dryopithecus itself had been removed (Begun, 2002). This situation will certainly change in the future, with some of the species and genera perhaps being combined and new ones found. Their characters are as follows: skulls with lightly built crania with relatively prominent brow ridges; variable prognathism from low to high; strong angle between face and skull (klinorhynchy) in Hispanopithecus laietanus; reduced maxillary sinus; broad triangular nose; broad palate; high zygomatic root; primitive teeth in $D$. fontani, molars with broad basins between cusps elongated molars and premolars in Pierolapithecus; teeth with thick enamel in Anoiapithecus and Pierolapithecus; reduced M3 in the three earlier species but not in $H$. laietanus and $R$. hungaricus; orthograde (upright) posture; broad chest region; long clavicle; scapula shifted on to back; stiff lumbar region; mobile elbow joint, stable at full extension; mobile wrist; long slender hand phalanges (short and less curved in some); femur head above greater trochanter; femur neck steeply angled.

Not all these characters are known for all species, but where they are known for two or more species the characters are consistent, with the conclusion that upright posture, and/or suspensory locomotion had evolved in some species of dryopithecines, particularly in Hispanopithecus laietanus (Crusafont-Pairo and Hurzeler, 1961; Pilbeam and Simons, 1971; Kretzoi, 1975; Morbeck, 1983; Begun et al., 1990, 2003; Moyà-Solà et al., 1993, 2004, 2009a, 2009b; Kordos, 1991; Begun and Kordos, 1993; Moyà-Solà S. and Köhler, 1993, 1995, 1996, 1997; Kordos and Begun 1997; Ungar and Kay 1995; Kordos and Begun, 1997; Kordos and Begun, 1997; Begun, 2002, 2009; Ungar, 2005; Alba et al., 2010; Begun et al., 
2012). Some of the characters supposedly indicating suspensory locomotion are absent in gibbons, the most suspensory of the apes, for example the stiff lower back. Similarly, the combination of mobility and stability in the elbow joint is seen as far back in time as the early Miocene in Proconsul heseloni, which had no suspensory adaptations. Crompton et al. (2008) points out that the adaptations of the trunk are related to upright posture, not necessarily to suspensory activity in trees, although it may be a pre-adaptation to the specialised brachiation in living gibbons. The large and elongated hand and cranial orientation of the head of the humerus are the two major adaptations that can be related to overhead suspension during locomotion, and these would certainly be pre-adaptations to gibbon-style locomotion.

The smaller dryopithecine species (15 to $35 \mathrm{~kg}$, Begun, 2002) have been found associated with subtropical to warm temperate swamp forests, with mesophytic broadleaved trees and deciduous conifers. These forests are deciduous and have open canopy, but there may have been a lower canopy of evergreen sclerophyllous bushes such as palms and laurels (Kretzoi et al., 1974; Axelrod, 1975; Myers and Ewel, 1990; Kovar-Eder et al., 1996; Kordos and Begun, 2002; Andrews and Cameron, 2010; Merceron et al., 2007; Marmi et al., 2012). There is no indication that these species of fossil ape were terrestrial.

More generally, all five dryopithecine species share some characters with the living great apes, and can be grouped with them in Hominidae. Some characters are shared only with the African great apes and others only with the orangutan. None are shared exclusively with gibbons, although the characters of the shoulder joint and hand are most similar to those of gibbons and orangutans, and it does not seem possible to link dryopithecines with one or other of the extant apes. The mosaic nature of evolutionary change depicted by the dryopithecines suggests that many of the cranial and dental similarities shared by the great apes evolved independently and should not be expected to be present in their common ancestor.

Mosaic evolution is also shown by the morphology of Oreopithecus bambolii, a late Miocene ape from Italy. It also had long arms, a broad thorax, short trunk, mobile hindlimbs, and powerful grasping hands and feet, and, like Hispanopithecus, it was adapted for forelimb suspension and arboreal climbing (Harrison, 1991; Harrison and Rook, 1997), but its skull and dental morphology show it to be different from the dryopithecines and probably an aberrant side branch of ape evolution.

Late Miocene fossil apes are less well known. A few fragmentary specimens have been recovered in Africa, but they are best known in Asian deposits, from Pakistan and India to Southeast Asia. Their associated habitats appear to be subtropical to tropical woodland (Badgley, 1984, 1989). Some of the species 
extend back into the middle Miocene, for example Sivapithecus sivalensis, and they are similar functionally to middle Miocene European apes, with relatively robust jaws and thick-enamelled teeth. Some have similarities of the skull with the orangutan, but the few postcrania show no suspensory adaptations and indicate a strong element of terrestriality in their locomotion (Pilbeam, 1982, 1996, 2004; Pilbeam et al., 1990; Rose, 1984, 1986, 1988, 1989, 1994, 1997). Laccopithecus robustus from late Miocene deposits in China is an ape similar to hylobatids in its skull and dental formation, but a single proximal phalanx is long and curved, like that of Hispanopithecus and gibbons (Wu and Pan, 1984; Meldrum and Pan, 1988; Begun, 2002).

In summary, the spectrum of fossil apes as known at present appears to have little or no bearing on the evolution of gibbons and nor, for that matter, to the great apes and humans. In 2006, Terry Harrison and PA tried to define the common ancestor between apes and humans by looking at the full extent of this spectrum, and we found that the last common ancestor of apes was probably not great-ape-like at all (Andrews and Harrison, 2006), and we suggest here that, similarly, the ancestral gibbons for most of their evolutionary history also did not look anything like recent gibbons.

\section{Divergence date of gibbons}

In the absence of fossil evidence, it has been proposed that the divergence of genera within the hylobatid clade was about $6 \mathrm{Ma}$. This is based in large part on the similarities in sequence diversity in mtDNA within the hylobatid clade and the African ape and human clade (Hayashi et al., 1995). Hylobatids are accepted as the outgroup to Hominidae (Hylobatidae(Hominidae(Ponginae(Ho mininae)))), and so, clearly, their separation from hominids must have predated the earliest divergence within Hominidae, that of the orangutan, and this gives a minimum age for the emergence of hylobatids. It has already been observed that the divergence of hylobatids from the great ape and human clade after that of the proconsulids does not itself give a maximum age of divergence. A minimum date is also provided by the uricase mutation mentioned above (and see below) of 13.1 to 9.8 Ma (Keebaugh and Thomas, 2010; Oda et al., 2002).

There are many unresolved issues in determining divergence ages. For a start, the calibration point from which molecular phylogenies are generated from DNA trees is that of the separation between monkeys and apes, and this is commonly taken to be about $30 \mathrm{Ma}$ (Raaum et al., 2005; Locke et al., 2011; Disotell, 2013). However, as Disotell points out, the earliest fossil apes or monkeys date to about $20 \mathrm{Ma}$, and there is no real basis for assuming a date much earlier than this. It is on the basis of a $30 \mathrm{Ma}$ split between monkeys and apes that the orangutan lineage is thought to have diverged at 12 to $13 \mathrm{Ma}$, but if the monkey/ape split 
was closer to $20 \mathrm{Ma}$, the orangutan divergence would have been closer to 9 or $10 \mathrm{Ma}$ and the separation of the gibbon lineage from other apes not much earlier than that.

The other main problem with the divergence of the orangutan lineage is that two species of fossil ape could be implicated. One is the Indian ape Sivapithecus sivalensis, the earliest record for which is about $12 \mathrm{Ma}$, and which gives a minimum age for the origin of the orangutan lineage (Pilbeam, 1996; Pilbeam et al., 1990). However, the postcranial skeleton of this fossil ape is nothing like that of the orangutan (Rose, 1984, 1986, 1989), whereas the skeleton and some aspects of the skull of Hispanopithecus laietanus from nine-million-year-old deposits in Spain have many similarities with the orangutan (Moyà-Solà and Köhler, 1996; Moyà-Solà et al., 2004, 2009a, 2009b). There is little likelihood, however, that $S$. indicus and $H$. laietanus are closely related, and it is clear that one or the other is converging on the orangutan, but which one? The fossils provide a range of dates of 9 to $12 \mathrm{Ma}$, and all we can say at present is that the gibbons branched off earlier.

\section{Hylobatid common ancestor}

To truly reflect evolutionary history, phylogenies must be based on characters inherited from recent ancestors, that is, homologous characters, and convergent, or non-homologous, homoplasies must be discarded. Further to this, the characters shared between two species are only significant in evolutionary terms if they were uniquely shared with their common ancestor, so that they are both homologous and derived relative to other species. Homology can sometimes be clearly evident, as for instance in the loss of the tail in all apes, but they can be difficult to distinguish from primitive retentions from an anthropoid ancestor. As new data are introduced into the analysis, the potential for error is compounded once the individual traits are combined into an ancestral morphotype. With this in mind, it is important to view ancestral morphotypes as approximations with relatively low resolution, rather than precise and accurate formulations of the ancestral condition. This is particularly important in stem forms where the proportion of potentially phylogenetically meaningful characters is small in relation to the number of primitive features, and the level of resolution may, therefore, exceed the capability to confidently differentiate their preserved anatomy from the ancestral morphotypes. If this is the case, there is a serious danger that the outcome of phylogenetic analyses might be influenced or skewed by the introduction of a few characters of uncertain or dubious utility.

From a theoretical perspective it may be argued that any common ancestor is essentially unknowable, because the characters by which it may be linked with its descendant species are not yet present. Closely related species are certain 
to share many characters as well as having developed different characters after their separation, but by the time that any one of these characters are present in a putative ancestor, it is no longer the common ancestor but belongs to one or other of the descendent lineages. For example, one of the most visible morphologies distinguishing living apes from all other primates is the loss of the tail, and any fossil primate lacking a tail, such as Proconsul, cannot be the common ancestor between monkeys and apes but must already be considered an ape. On the other hand, the common ancestor of apes and monkeys could have had a tail without being placed on the line leading to monkeys, for all other primates have tails, and this is the ancestral condition for all primates, primitively retained by monkeys. It is likely, therefore, that the common ancestor of apes and monkeys had a tail, but this does not help to identify it, just as lack of tail would disqualify it as the common ancestor.

Similarly with the gibbons: they share a whole suite of characters relating to their suspensory locomotion and orthograde posture, and this shows them to be a monophyletic group. Absence of some or even most of these characters would not exclude any fossil ape from being ancestral to gibbons before they began to speciate, and several possible scenarios for gibbon ancestry can be suggested and potentially tested against future fossil evidence. One such scenario is that the gibbon lineage will show the progressive acquisition of suspensory characters. In this scenario, it is suggested that early gibbon ancestors retained mainly primitive catarrhine characters, with a gradually developing suite of suspensory and orthograde adaptations, most of which were almost certainly acquired independently of the great apes and humans. Two examples illustrate this. Dendropithecus macinnesi from $18 \mathrm{Ma}$ in Africa had clear suspensory adaptations, but they were analogous with those of colobine or ateline monkeys, and they cannot be identified with any certainty as being homologous with gibbons. Evidence is lacking to show if the fossil species was orthograde or not. Similarly, the late Miocene Laccopithecus robustus from China combined primitive skull morphology with a single phalanx that also showed tantalising evidence of suspensory locomotion. Either or both could be ancestral to gibbons, but it is also the case that there were many other small-sized catarrhine primates in the Miocene, any one of which could have given rise to the gibbons.

An alternative scenario is that the gibbon lineage arose out of one of the lineages already known to have well developed suspensory adaptations, for example from Hispanopithecus laietanus. The adaptations of the upper arm and shoulder, the greatly elongated hand and the cranial orientation of the head of the femur could all be precursors to the highly specialised suspensory adaptations in living gibbons. Reduction in size, with increasingly gracile skulls, is not a major evolutionary step. Shea (2013) has shown that many of the apparent differences in the skull between great apes and gibbons is due 
to their size differences, characters such as palate depth, naso-alveolar clivus morphology, nasal aperture size and shape and the height of the zygomatic root. It is apparent that reduction in body weight by about 50 per cent of a fossil ape such as Hispanopithecus laietanus would leave its skull close to the morphology of gibbon skulls. The apparent adaptation of this dryopithecine, together with that of Rudapithecus hungaricus, to below branch suspensory locomotion in warm temperate to subtropical swamp forests in southern Europe (Merceron et al., 2007; Andrews and Cameron, 2010; Marmi et al., 2012) could have led to increasing specialisation to life in tropical rainforests.

A third scenario can be based on evidence of the mutation leading to the shutting down of the uricase gene. Uricase is an enzyme that breaks down uric acid, and exists in all mammals except the hominoids. There is evidence that the uricase enzyme progressively lost its activity in hominoids during the early Miocene due to mutations in its promoter region (Oda et al., 2002). However, complete silencing of the uricase gene occurred separately in the great ape-human clade (in codon 33 of exon 2) and in the hylobatids (in codon 18 of exon 2) during the midMiocene. The timing of the uricase mutations is not known with certainty, but it has been calculated in the great ape-human clade to have occurred either 12.9 Ma (Keebaugh and Thomas, 2010), 15.4 Ma (Oda et al., 2002), or between 15.7 and $20 \mathrm{Ma}$ (Eric Gaucher, pers. comm.), respectively. The silencing mutation in the hylobatid lineage has been estimated to occur at 13.1 Ma (Keebaugh and Thomas, 2010) or 9.8 Ma (Oda et al., 2002) based on proposed separations of the hominoids and Old World monkeys at $23 \mathrm{Ma}$ and of the Catarrhini and hominoids at $35 \mathrm{Ma}$, respectively. The presence of a monkey-like tooth in 25 Ma deposits of the Nsungwe Formation (Stevens et al., 2013) suggests an earlier divergence of monkeys and apes. These data are also consistent with a separation of hylobatids from the great ape-human lineage between 15 and 20 Ma.

It has been hypothesised that the loss of the uricase gene had a positive adaptive function in the great ape and human clade (Johnson and Andrews, 2010). For fruit eaters such as gibbons, this might appear to be a serious matter, for fructose, the primary sugar present in fruit, stimulates fat synthesis and accumulation due in part to an increase in intracellular and serum uric acid that occurs as a consequence of its unique metabolism (Lanaspa et al., 2012). The ability of fructose to stimulate fat accumulation in the liver is enhanced when uricase is inhibited (Tapia et al., 2013). The uric acid generated by fructose also has an important role in driving the elevations in serum triglycerides, induction of insulin resistance, and elevations in blood pressure in response to fructose (Nakagawa et al., 2006). Therefore, the loss of uricase may have enhanced the ability of gibbons and other ancestral apes to increase their fat stores from the ingestion of ripe fruits rich in fructose that could aid survival through the adverse conditions in seasonal habitats (Johnson and Andrews, 2010). In this 
scenario, it may be that the late Miocene gibbon ancestors passed through a traumatic phase in increasingly hostile environments before ending up in the rich tropical rainforests of Asia.

Whichever of these scenarios proves to be correct, or any other not so far proposed, it is evident from molecular studies that the gibbon radiation was recent and rapid, either as a vicariant event or extremely rapid radiation (Thinh et al., 2010; Israfil et al., 2011; Disotell, 2013). The trigger for this was probably the rise and fall of sea levels, combined with expansion and contraction of the Southeast Asian rainforests during the glaciations (Geissmann, 1995; BrandonJones, 1998). This diversification, however, probably took place during the last two to three million years, and it does not answer the question of what prompted the emergence of the highly specialised gibbon adaptations.

\section{Acknowledgements}

We are grateful to the organisers and editors of the book to honour the many contributions made by Colin Groves. Working with Colin has always been enjoyable and stimulating, both in the field on the Tana River project, and in the laboratory, when we did our work on gibbon morphology. PA benefited greatly from the association and owes much to Colin during a crucial stage of his career.

\section{References}

Aiello LC. 1981. The allometry of primate body proportions. In: Stringer CB, editor. Aspects of human evolution. London: Taylor \& Francis. pp. 331-358.

Alba DM, Fortuny J, Moyà-Solà S. 2010. Enamel thickness in the middle Miocene great apes Anoiapithecus, Pierolapithecus and Dryopithecus. Proc R Soc Lond 277:2237-2245.

Alpagut B, Andrews P, Martin L. 1990. New hominoid specimens from the middle Miocene site at Paşalar, Turkey. J Hum Evol 19:397-422.

Alpagut B, Andrews P, Fortelius M, Kappelman J, Temizsoy I, Celebi H, Lindsay W. 1996. A new specimen of Ankarapithecus meteai from the Sinap Formation of central Anatolia. Nature 382:349-351.

Andrews P. 1978. A revision of the Miocene Hominoidea of East Africa. Bull $\mathrm{Br}$ Mus Nat Hist (Geol) 30:85-224. 
Taxonomic Tapestries

Andrews P. 1992. Evolution and environment in the Hominoidea. Nature 360:641-646.

Andrews P, Cameron D. 2010. Rudabànya: Taphonomic analysis of a fossil hominid site from Hungary. Palaeogeog, Palaeoclimat, Palaeoecol 297:311329.

Andrews P, Groves CP. 1976. Gibbons and brachiation. In: Rumbaugh D, editor. Gibbon and Siamang, Vol. 4. Basel: Karger. pp. 167-218.

Andrews P, Harrison T. 2005. The last common ancestor of apes and humans. In: Lieberman DE, Smith RJ, Kelley J, editors. Interpreting the past: Essays on human, primate, and mammal evolution in honor of David Pilbeam. Boston: Brill Academic Publishers. pp. 103-121.

Andrews P, Simons EL. 1977. A new African gibbon-like genus Dendropithecus (Hominoidea, Primates) with distinctive postcranial adaptations: Its significance to origin of Hylobatidae. Folia Primatol 28:161-169.

Ashton EH, Oxnard CE. 1963. The musculature of the primate shoulder. Trans Zool Soc Lond 29:553-650.

Ashton EH, Oxnard CE. 1964. Locomotor patterns in primates. Proc Zool Soc Lond 142:1-28.

Avis V. 1962. Brachiation: The crucial issue for man's ancestry. Southwestern J Anthrop 18:119-148.

Axelrod DI. 1975. Evolution and biogeography of the Madrean-Tethyan sclerophyll vegetation. Ann Miss Bot Garden 62:280-334.

Bacon A-M, Long VT. 2001. The first discovery of a complete skeleton of a fossil orang-utan in a cave of the Hoa Binh Province, Vietnam. J Hum Evol 41:227241.

Badgley C. 1984. The palaeoenvironment of South Asian Miocene hominoids, In: White RD, editor. The evolution of East Asian environments. Hong Kong: Centre for Asian Studies. pp. 796-811.

Badgley C. 1989. Community analysis of Siwalik mammals from Pakistan. $J$ Vert Paleont 9:11A.

Beard KC, Teaford MF, Walker A. 1986. New wrist bones of Proconsul africanus and P. nyanzae from Rusinga Island, Kenya. Folia Primatol 47:97-118.

Begun DR. 2002. European hominoids. In: Hartig WC, editor. The primate fossil record. Cambridge: Cambridge University Press. pp. 339-368. 
Begun DR. 2009. Dryopithecins, Darwin, de Bonis and the European origin of the African apes and human clade. Geodiversitas 31:789-816.

Begun DR, Geraads D, Guleç E. 2003. The Çandır hominoid locality: Implications for the timing and pattern of hominoid dispersal events. Courier Forsch Senckenberg 240:251-265.

Begun DR, Güleç E. 1998. Restoration of the type and palate of Ankarapithecusmeteai: Taxonomic and phylogenetic implications. Am J Phys Anthrop 105:279-314.

Begun DR, Kordos L. 1993. Revision of Dryopithecus brancoi Schlosser, 1910, based on the fossil hominid material from Rudabanya. J Hum Evol 25:271286.

Begun DR, Moyá-Sola S, Köhler M. 1990. New Miocene hominoid specimens from Can Llobateres (Valles Penedes, Spain) and their geological and paleoecological context. J Hum Evol 9:255-268.

Begun DR, Nargolwalla MC, Kordos L. 2012. European Miocene hominids and the origin of the African ape and human clade. Evol Anthrop 21:10-23.

Begun DR, Teaford MF, Walker A. 1994. Comparative and functional anatomy of Proconsul phalanges from the Kaswanga primate site, Rusinga Island, Kenya. J Hum Evol 26:89-165.

Biegert J, Maurer R. 1972. Rumpfskelettlange, Allometrien und Korperproportionen bei catarrhinen Primaten. Folia Primatol 17:142-156.

Brandon-Jones D. 1998. Pre-glacial Bornean primate impoverishment and Wallace's line. In: Hall R, Holloway JD, editors. Biogeography and geological evolution of SE Asia. Leiden: Blackhuys Publishers. pp. 393-403.

Brandon-Jones D, Eudey AA, Geissmann T, Groves CP, Melnick DJ, Morales JC, Shekelle M, Stewart C-B. 2004. Asian primate classification. Int J Primatol 25:97-164.

Collinson ME, Andrews P, Bamford M. 2009. Taphonomy of the early Miocene flora, Hiwegi Formation, Rusinga Island, Kenya. J Hum Evol 57:149-162.

Crompton RH, Vereeke EE, Kalb JE. 2008. Locomotion and posture from the common hominoid ancestor to fully modern hominins, with special reference to the common Panin/Hominin ancestor. J Anat 212:501-543.

Crusafont-Pairó M, Hürzeler J. 1961. Les pongidés fossilles d'Espagne. Comptes Rendus bebdomadaires d l'Academie des Sciences Paris 254:582-584. 
Delson E. 1977. Vertebrate paleontology, especially of non-human primates from China. In: Howells WW, Tsuchitani PJ, editors. Paleoanthropology in the People's Republic of China. Washington: National Academy of Sciences, pp. 40-65.

Disotell TR. 2013. Genetic perspectives on ape and human evolution. In: Begun DR, editor. A companion to paleoanthropology. Oxford: Wiley-Blackwell. pp. 291-305.

Ersoy A, Kelley J, Andrews P, Alpagut B. 2008. Hominoid phalanges from the middle Miocene site of Paşalar, Turkey. J Hum Evol 54:518-529.

Gebo DL, Beard KC, Teaford MF, Walker A, Larson SG, Jungers WL, Fleagle JG. 1988. A hominoid proximal humerus from the early Miocene of Rusinga Island, Kenya. J Hum Evol 17:393-401.

Gebo DL, Malit NR, Nengo IO. 2009. New proconsuloid postcranials from the early Miocene of Kenya. Primates 50:311-319.

Geissmann T. 1995. Gibbon systematics and species identification. Zoo News 42:467-501.

Goodman M, Porter CA, Czelnusiak J, Page SL, Schneider H, Shoshani J, Gunnell G, Groves CP. 1998. Towards a phylogenetic classification of primates based on DNA evidence complemented by fossil evidence. Mol Phyl Evol 9:585598.

Groves CP. 1972. Systematics and phylogeny of gibbons. In: Rumbaugh D, editor. Gibbon and Siamang, Vol. 1. Basel: Karger. pp. 1-89.

Groves CP. 2001. Primate taxonomy. Washington, DC: The Smithsonian Institution.

Harrison T. 1991. The implications of Oreopithecus for the origins of bipedalism. In: Coppens Y, Senut B, editors. Origine(s) de la Bipédie Chez les Hominidés. Paris: Cahiers de Paléoanthropologie, CNRS. pp. 235-244.

Harrison T. 1992. A reassessment of the taxonomic and phylogenetic affinities of the fossil catarrhines from Fort Ternan, Kenya. Primates 33:501-522.

Harrison T. 2002. Late Oligocene to middle Miocene catarrhines from AfroArabia. In: Hartwig WC, editor. The primate fossil record. Cambridge: Cambridge University Press. pp. 311-338. 
Harrison T, Rook L. 1997. Enigmatic anthropoid or misunderstood ape? The phylogenetic status of Oreopithecus bambolii reconsidered. In: Begun, DR, Ward CV, Rose MD, editors. Function, phylogeny, and fossils: Miocene hominoid evolution and adaptations. New York: Plenum Press. pp. 327-362.

Hayashi S, Hayasaka K, Takenaka O, Horai S. 1995. Molecular phylogeny of gibbons inferred from mitochondrial DNA sequences: Preliminary report. $J$ Mol Evol 41:359-365.

Hooijer DA. 1960. Quaternary gibbons from the Malay archipelago. Zool Verh Mus Leiden 46:1-42.

Ishida H, Kunimatsu Y, Nakatsukasa M, Nakano Y. 1999. New hominoid genus from the middle Miocene of Nachola. Anthropological Science 107:189-191.

Ishida H, Kunimatsu Y, Takano T, NakanoY, Nakatsukasa M. 2004. Nacholapithecus skeleton from the Middle Miocene of Kenya. J Hum Evol 46:69-103.

Israfil H, Zehr SM, Mootnick AR, Ruvolo M, Steiper ME. 2011. Unresolved molecular phylogenies of gibbons and siamangs (Family Hylobatidae) based on mitochondrial, Y-linked and X-linked loci indicate a rapid Miocene radiation or sudden vicariance event. Mol Phyl Evol 58:447-455.

Johnson RJ, Andrews P. 2010. Fructose, uricase, and the back to Africa hypothesis. Evol Anthrop 19:250-257.

Jungers WL. 1984. Aspects of size and scaling in primate biology with special reference to the locomotor skeleton. Yrbk Phys Anthrop 27:73-97.

Keebaugh AC, Thomas JW. 2010. The evolutionary fate of the genes encoding the purine catabolic enzymes in hominoids, birds, and reptiles. Mol Biol Evol 27:1359-1369.

Kay, RF. 1977. Diet of early Miocene African hominoids. Nature 268:628-630.

Kelley J. 2002. The hominoid radiation in Asia. In: Hartwig WC, editor. The primate fossil record. Cambridge: Cambridge University Press. pp. 339-368.

Kelley J. 2008. Identification of a single birth cohort in Kenyapithecus kizili and the nature of sympatry between K. kizili and Griphopithecus alpani at Paşalar. J Hum Evol 54:530-537.

Kelley J, Andrews P, Alpagut B. 2008. A new hominoid species from the middle Miocene site of Paşalar, Turkey. J Hum Evol 54:455-479.

Kelley J, Ward S, Brown B, Hill A, Downs W. 2000. Middle Miocene hominoid origins: Response. Science 287:2375a. 
Taxonomic Tapestries

Kelley J, Ward S, Brown, B, Hill A, Duren DL. 2002. Dental remains of Equatorius africanus from Kipsaramon, Tugen Hills, Baringo District, Kenya. J Hum Evol 42:39-62.

King T, Aiello L, Andrews P. 1999. Dental microwear of Griphopithecus alpani. J Hum Evol 36:3-31.

Kordos L. 1991. Le Rudapithecus hungaricus de Rudabànya (Hongrie). L'Anthropologie 95:343-362.

Kordos L, Begun DR. 1997. A new reconstruction of RUD 77, a partial cranium of Dryopithecus brancoi from Rudabánya, Hungary. Am J Phys Anthrop 103:277-294.

Kordos L, Begun DR. 2002. Rudabánya: A late Miocene subtropical swamp deposit with evidence of the origin of the African apes and humans. Evol Anthrop 11:45-57.

Kovar-Eder J, Kvacek Zastawniak E, Givulescu R, Hably L, Mihajlovic D, Teslenko J, Walther H. 1996. Floristic trends in the vegetation of the Paratethys surrounding areas during Neogene times. In: Bernor RL, Fahlbusch V, Mitmann H-W, editors. The evolution of Western Eurasian Neogene mammal faunas. New York: Columbia University Press. pp. 395-413.

Kretzoi M. 1975. New ramapithecines and Pliopithecus from the lower Pliocene of Rudabànya in northeastern Hungary. Nature 257:578-581.

Kretzoi M, Krolopp E, Lorincz H, Palfalvy I. 1974. A Rudabanyai Alsopannonai prehominidas lelohely floraja, faunaja es retegtani helyzete. M All Foldtani Intezet Evi Jelentezi 1974:365-394.

Lanaspa MA, Sanchez-Lozada LG, Choi YJ et al. 2012. Uric acid induces hepatic steatosis by generation of mitochondrial oxidative stress: Potential role in fructose-dependent and -independent fatty liver. J Biol Chem 287:40732-44.

Le Gros Clark WE, Leakey LSB. 1951. The Miocene Hominoidea of East Africa. London: British Museum (Natural History).

Le Gros Clark WE, Thomas DP. 1951. Associated jaws and limb bones of Limnopithecus macinnesi. London: British Museum (Natural History).

Lewis OJ. 1971. Brachiation and the early evolution of the Hominoidea. Nature 203:577-579.

Lewis OJ. 1989. Functional morphology of the evolving hand and foot. Oxford: Clarendon Press. 
Locke DP, Hillier LW, Warren WC, Worley KC, Nazareth LV, Muzny DM, Yang S-P, Wang Z, Chinwall AT, Minx P. 2011. Comparative and demographic analysis of orang utan genomes. Nature 469:529-533.

McBrearty S, Jablonsky NG. 2005. First fossil chimpanzee. Nature 437:105-108.

McCrossin ML, Benefit BR. 1997. On the relationships and adaptations of Kenyapithecus, a large-bodied hominoid from the middle Miocene of eastern Africa. In: Begun DR, Ward CV, Rose MD, editors. Function, phylogeny and fossils: Miocene hominoid evolution and adaptations. New York: Plenum Press. pp. 241-267.

McCrossin ML, Benefit BR, Gitau SN, Palmer AK, Blue KT. 1998. Fossil evidence for the origin of terrestriality among Old World higher primates. In: Strasser E, Fleagle J, Rosenberger A, McHenry H, editors. Primate locomotion: Recent advances. New York: Plenum Press. pp. 353-396.

Marmi J, Casanovas-Vilar I, Robles JM, Moyá-Sola S, Alba DM. 2012. The paleoenvironment of Hispanopithecus laietanus as revealed by paleobotanical evidence from the late Miocene of Can Llobateres 1 (Catalonia, Spain). J Hum Evol 62:412-423.

Matthews WD, Granger W. 1923. New fossil mammals from the Pliocene of Szechuan, China. Bull Amer Mus Nat Hist 48:563-598.

Meldrum DJ, Pan Y. 1988. Manual proximal phalanx of Laccopithecus robustus from the latest Miocene site of Lufeng. J Hum Evol 17:719-731.

Merceron G, Schulz E, Kordos L Kaiser TM. 2007. Paleoenvironment of Dryopithecus brancoi at Rudabánya, Hungary: Evidence from dental mesoand micro-wear analyses of large vegetarian mammals. J Hum Evol 53:331349

Morbeck ME. 1983. Miocene hominoid discoveries from Rudabánya: Implications from the postcranial skeleton. In: Ciochon RL, Corruccini RS, editors, New interpretations of ape and human ancestry. New York: Plenum Press. pp. 369-404.

Moyà-Solà S, Alba DM, Almecija S, Casanovas-Vilar I, Köhler M, EstebanTrivigno S de, Robles JM, Galindo J, Fortuny J. 2009a. A unique middle Miocene European hominoid and the origins of the great ape and human clade. PNAS 106:1-6.

Moyà-Solà S, Köhler M. 1993. Recent discoveries of Dryopithecus shed new light on evolution of great apes. Nature 365:543-545. 
Taxonomic Tapestries

Moyà-Solà S, Köhler M. 1995. New partial cranium of Dryopithecus Lartet, 1863 (Hominoidea, Primates) from the upper Miocene of Can Llobateres, Barcelona, Spain. J Hum Evol 29:101-139.

Moyà-Solà S, Köhler M. 1996. The first Dryopithecus skeleton: Origins of great ape locomotion. Nature 379:156-159.

Moyà-Solà S, Köhler M. 1997. The phylogenetic relationships of Oreopithecus bambolii Gervais, 1872. C R Acad Sciences 324:141-148.

Moyà-Solà S, Köhler M, Alba DM, Casanovas-Vilar I, Galindo J. 2004. Pierolapithecus catalaunicus, a new middle Miocene great ape from Spain. Science 306:1339-1344.

Moyà-Solà S, Köhler M, Alba DM, Casanovas-Vilar I, Galindo J, Robles JM, Cabrera L, Garces M, Almecija S, Beamud E. 2009b. First partial face and upper dentition of the middle Miocene hominoid Dryopithecus fontani from Abocador de Can Mata (Valles-Penedes Basin, Catalonia, NE Spain): Taxonomic and phylogenetic implications. Am J Phys Anthrop 139:126-145.

Myers RL, Ewel JJ. 1990. Ecosystems of Florida. Gainesville: University of Central Florida Press.

Nakagawa T, Hu H, Zharikov S et al. 2006. A causal role for uric acid in fructoseinduced metabolic syndrome. Am J Physiol Renal Physiol 290:F625-631.

Nakatsukasa M. 2008. Comparative study of Moroto vertebral specimens. $J$ Hum Evol 55:581-588.

Nakatsukasa M, Kunimatsu Y, Nakano Y, Ishida H. 2007. Vertebral morphology of Nacholapithecus kerioi based on KNM-BG 35250. J Hum Evol 52:347-369.

Nakatsukasa M, Yamanaka A, Kunimatsu Y, Shimizu D, Ishida H. 1998. A newly discovered Kenyapithecus skeleton and its implications for the evolution of positional behaviour in Miocene East African hominoids. J Hum Evol 34:657-664.

Napier JR. 1960. Studies of the hands of living primates. Proc Zool Soc Lond 134:647-657.

Napier JR. 1963. Brachiation and brachiators. Symp Zool Soc Lond 10:183-195.

Napier JR, Davis PR. 1959. The fore-limb skeleton and associated remains of Proconsul africanus. London: British Museum (Natural History).

Oda M, Satta Y, Takenaka O, Takahata N. 2002. Loss of urate oxidase activity in hominoids and its evolutionary implications. Mol Biol Evol 19(5):640-653. 
Pickford M, Senut B. 2005. Hominoid teeth with chimpanzee- and gorilla-like features from the Miocene of Kenya: Implications for the chronology of apehuman divergence and biogeography of Miocene hominoids. Anthrop Sci 113:95-102.

Pilbeam DR. 1982. New hominoid skull material from the Miocene of Pakistan. Nature 295:232-234.

Pilbeam DR. 1996. Genetic and morphological records of the Hominoidea and hominid origins: A synthesis. Mol Phyl Evol 5:155-168.

Pilbeam DR. 2004. The anthropoid postcranial axial skeleton: Comments on development, variation and evolution. J Experiment Zool 302:241-267.

Pilbeam DR, Rose MD, Barry JC, Shah MI. 1990. New Sivapithecus humeri from Pakistan and the relationship of Sivapithecus and Pongo. Nature 348:237-239.

Pilbeam DR, Simons EL. 1971. Humerus of Dryopithecus from Saint Gaudens, France. Nature 229:406-407.

Preuschoft H, Chivers DJ, Brockelman WY, Creel N. 1984. The Lesser Apes: Evolutionary and Behavioural Biology. Edinburgh: Edinburgh University Press.

Raaum R, Sterner KN, Noviello CM, Stewart C-B, Disotel DR. 2005. Catarrhine primate divergence dates estimated from complete mitochondrial genomes: Concordance with fossil and nuclear DNA evidence. J Hum Evol 48:237-257.

Rafferty KL. 1998. Structural design of the femoral neck in primates. J Hum Evol 34:361-383.

Rafferty K, Walker A, Ruff C, Rose M, Andrews P. 1995. Postcranial estimates of body weight in Proconsul, with a note on a distal tibia of P. major from Napak, Uganda. Am J Phys Anthrop 97:391-402.

Rose MD. 1983. Miocene hominoid postcranial morphology: Monkey-like ape-like, neither, or both? In: Ciochon RL, Corruccini RS, editors. New interpretations of ape and human ancestry. New York: Plenum Press. pp. 405417.

Rose MD. 1984. Hominoid postcranial specimens from the middle Miocene Chinji Formation, Pakistan. J Hum Evol 13:503-516.

Rose MD. 1986. Further hominoid postcranial specimens from the late Miocene Nagri Formation of Pakistan. J Hum Evol 15:333-367.

Rose MD. 1988. Another look at the anthropoid elbow. J Hum Evol 17:193-224. 
Rose MD. 1989. New postcranial specimens of catarrhines from the middle Miocene Chinji Formation, Pakistan: Descriptions and a discussion of proximal humeral functional morphology in anthropoids. J Hum Evol 18:131-162.

Rose MD. 1994. Quadrupedalism in some Miocene catarrhines. J Hum Evol 26:387-411.

Rose MD. 1997. Functional and phylogenetic features of the forelimb in Miocene hominoids. In: Begun DR, Ward CV, Rose MD, editors. Function, phylogeny and fossils: Miocene hominoid evolution and adaptations. New York: Plenum Press. pp. 79-100.

Schultz AH. 1973. The skeleton of the Hylobatidae and other observations on their morphology. In: Rumbaugh DM, editor. Gibbon and Siamang, Vol. 2. Basel: Karger. pp. 1-54.

Simons EL, Pilbeam DR. 1965. A preliminary revision of the Dryopithecinae. Folia Primatol 3:81-152.

Stevens, NJ, Seiffert ER, O'Connor PM, Roberts EM, Schmitz, MD, Krause C, Gorscak E, Ngasala S, Hieronymus TL, Temu J. 2013. Palaeontological evidence for an Oligocene divergence between Old World monkeys and apes. Nature, published online 15 April 2013.

Tapia E et al. 2013. Synergistic effect of uricase blockade plus physiological amounts of fructose-glucose on glomerular hypertension and oxidative stress in rats. Am J Physiol Renal Physiol 304:F727-36.

Teaford MF. 1988. A review of dental microwear and diet in modern mammals. Scanning Microsc 2:1149-1166.

Teaford MF. 1991. Dental microwear: What can it tell us about diet and dental function? In: Else J, Lee P, editors. Advances in dental anthropology. New York: Wiley-Liss Inc. pp. 341-356.

Teaford MF. 1994. Dental microwear and dental function. Evol Anthrop 3:17-30.

Tekkaya I. 1974. A new species of anthropoid (Primates, Mammalia) from Anatolia. Bull Min Explor Inst, Ankara (MTA) 83:148-165.

Thinh VN, Mootnick AR, Geissmann T, Li M, Ziegler T, Agil M, Moisson P, Nadler T, Walter L, Roos C. 2010. Mitochondrial evidence for multiple radiations in the evolutionary history of small apes. BMC Evol Biol 10: 74. 
Ungar PS. 2005. Dental evidence for the diets of fossil primates from Rudabánya, Northeastern Hungary with comments on extant primate analogs and 'noncompetitive' sympatry. Palaeont Ital 90:97-112.

Ungar PS, editor. 2007. Evolution of the human diet. Oxford: Oxford University Press.

Ungar PS, Kay RF. 1995. The dietary adaptations of European Miocene catarrhines. PNAS 93:5479-5481.

Walker AC, Falk D, Smith R, Pickford M. 1983. The skull of Proconsul africanus: Reconstruction and cranial capacity. Nature 305:525-527.

Walker A, Pickford M. 1983. New postcranial fossils of Proconsul africanus and Proconsul nyanzae. In: Ciochon RL, Corruccini RS, editors. New interpretations of ape and human ancestry. New York: Plenum Press. pp. 325-351.

Walker A, Teaford M. 1988. The hunt for Proconsul. Scient Am 260:76-82.

Walker A, Teaford M. 1989. The Kaswanga primate site: An early Miocene hominoid site on Rusinga Island, Kenya. J Hum Evol 17:539-544.

Walker A, Teaford M, Martin L, Andrews P. 1993. A new species of Proconsul from the early Miocene of Rusinga/Mwangano Islands, Kenya. J Hum Evol 25:43-56.

Ward CV. 1993. Torso morphology and locomotion in Proconsul nyanzae. Am J Phys Anthrop 92:291-328.

Ward CV, Ruff CB, Walker A, Teaford MF, Rose MD, Nengo IO. 1995. Functional morphology of Proconsul patellas from Rusinga Island, Kenya, with implications for other Miocene-Pliocene catarrhines. J Hum Evol 29:1-19.

Ward CV, Walker A, Teaford MF. 1991. Proconsul did not have a tail. J Hum Evol 21:215-220.

Ward CV, Walker A, Teaford MF, Odhiambo I. 1993. Partial skeleton of Proconsul nyanzae from Mfangano Island, Kenya. Am J Phys Anthrop 90:77-111.

Wu R, Pan Y. 1984. A late Miocene gibbon-like primate from Lufeng, Yunnan Province. Acta Anthrop Sin 3:185-194. 
This text is taken from Taxonomic Tapestries: The Threads of Evolutionary, Behavioural and Conservation Research, edited by Alison M Behie and Marc F Oxenham, published 2015 by ANU Press, The Australian National University, Canberra, Australia. 